International Journal of Oceanography and Hydrobiology Volume 50, No. 4, December 2021

\title{
Analysis of heavy metal contamination in surface sediments of Iskenderun Bay, Turkey
}

by

\author{
Banu Kutlu',*, Tahir Özcan², \\ Gülnaz Özcan²
}

\section{DOI: 10.2478/oandhs-2021-0035 \\ Category: Original research paper \\ Received: March 31, 2021 \\ Accepted: June 23, 2021}

'Basic Science Department, Fisheries Faculty, Munzur University, TR-62000 Tunceli,

Turkey

2iskenderun Technical University, Faculty of Marine Sciences and Technology, TR-31200 Iskenderun-Hatay, Turkey

* Corresponding author: kutlubanu@gmail.com

\section{Abstract}

The ecological risk resulting from the accumulation of some heavy metals in the sediments of Iskenderun Bay was assessed using the following measures: enrichment and contamination factor, pollution load index (PLI), and potential ecological risk index $(R I)$. The concentrations of the studied heavy metals were in the following order: $\mathrm{Fe}>\mathrm{Ni}$ $>\mathrm{Mn}>\mathrm{Cr}>\mathrm{Zn}>\mathrm{Cu}>\mathrm{As}>\mathrm{Pb}>\mathrm{Cd}>\mathrm{Hg}$. Ni and As had the highest EF values. This situation is most likely due to the presence of iron, pesticide, and fertilizer plants in the region. According to the United States Environmental Protection Agency, Ni, As, Mn, and Cr may have harmful effects on faunal communities in sediments. According to the $R l$, Site 4 was more contaminated and toxic than the other seven study sites, with "moderate" ecological risk. Pearson's correlation coefficient was determined by multivariate methods cluster and principal component analysis. As can be inferred from the $R /$ values, the potential toxic effect of $\mathrm{As}$ and $\mathrm{Ni}$ in the sediments is moderate.

Key words: environmental pollution, environmental risk assessment, heavy metals, accumulation, Iskenderun Bay, Mediterranean Sea 


\section{Introduction}

As a result of technological development, heavy metal pollution has become a threat to life. Many adverse effects of metal pollution on the aquatic environment have been identified. Heavy metal pollution in the aquatic environment derives from natural sources such as air, soil, and dissolved mineral rocks (Adamu et al. 2015; Skordas et al. 2015), as well as anthropogenic sources such as domestic, industrial, and agricultural effluents (Wei \& Yang 2010; Mohiuddin et al. 2010).

The discharge, storage, and precipitation of heavy metals occur in marine and oceanic sediments (Fujita et al. 2014; Machado et al. 2016). Sediments are a good indicator of heavy metals from anthropogenic sources due to the hydrophobic properties of the latter and their tendency to accumulate with precipitation. Sediment analysis provides information on total accumulation (Anderson Abel et al. 2016). Sedimentation is very important for the accumulation of heavy metals in the hydrological cycle in the aquatic environment. Heavy metals are not completely immobilized in the surface sediment, which is a biological, physicochemical, hydrological, and geological interaction area in a complex system. Instead, they migrate and sometimes accumulate (Dhanakumar et al. 2015; Chen et al. 2019).

In order to determine metal contamination sources in the aquatic environment, it is important to examine changes in natural and anthropogenic trace elements (Bing et al. 2013). For this purpose, indices such as the enrichment factor $(E F)$, the contamination factor (CF), and the geoaccumulation index (Igeo) are employed to identify whether metals originate from natural geological structures, and the potential ecological risk index $R I$ is frequently used to assess the ecological risk (Yang et al. 2014; Bing et al. 2013; Long et al. 2006; Hou et al. 2013). The $R l$ is commonly preferred along with principal component analysis (PCA) and cluster analysis (CA) to characterize pollutant emissions (Huang et al. 2018).

Pollution has become a serious issue in countries bordering the Mediterranean Sea. The semi-enclosed structure of this ecosystem and the increase in population density along the Mediterranean coastline have caused considerable water pollution. In order to mitigate this problem, a comprehensive pollution prevention and control program (Mediterranean Action Plan), organized and supported by the United Nations and various international agencies, has been implemented by the Mediterranean countries since 1975. A number of researchers have reported that many trace metals, from either natural or anthropogenic sources, enter the Mediterranean Sea in different parts of this ecosystem (Cubadda et al. 2001).

Previous studies investigated the presence and effects of heavy metals on seawater and sediment in Iskenderun Bay (Türkmen \& Aras 2011) focusing on sediment and benthos (Dural and Göksu 2006; Türkmen \& Aras 2011), marine algae (Olgunoğlu \& Polat 2007), aquatic vertebrates (Kargın et al. 2006; Kalay et al. 1999), and aquatic invertebrates (Duysak et al. 2013; Duysak \& Ersoy 2014).

The objectives of this study were to determine the accumulation and distribution of ten heavy metals (i.e. $\mathrm{Cu}, \mathrm{Pb}, \mathrm{Zn}, \mathrm{Ni}, \mathrm{Mn}, \mathrm{Fe}, \mathrm{As}, \mathrm{Cd}, \mathrm{Cr}$ and $\mathrm{Hg}$ ) in sediments collected from eight sites located in different regions of Iskenderun Bay. Furthermore, we calculated the contamination factor, the pollution load index, and the potential ecological risk index $(R I)$ to determine whether the source of pollution was natural or anthropogenic.

\section{Materials and methods}

Two-period sampling was performed to cover the Iskenderun, Yumurtalık, and Arsuz regions in the northern and southern parts of the study area, i.e. Iskenderun Bay (Fig. 1).

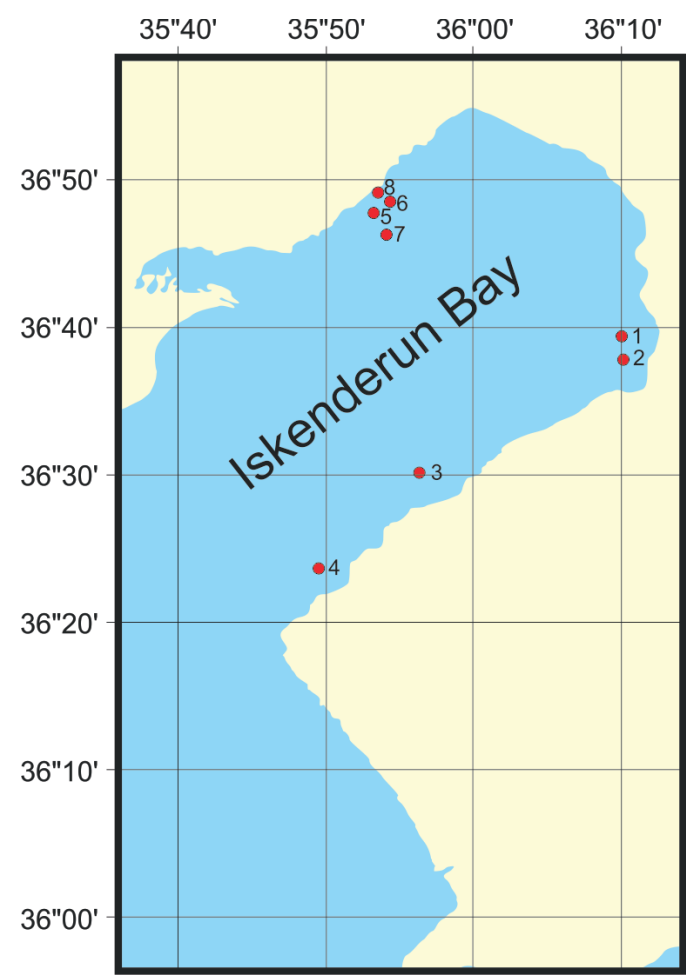

Figure 1

Iskenderun Bay sampling area 
Surface sediment samples were collected at the selected sites in the study area on 8 April 2018 and 8 June 2019, using a van Veen grab sampler (Table 1). Samples were homogenized and placed in plastic bags before being transferred to Petri dishes pre-washed with acid and RO purified water in the laboratory. Samples in Petri dishes were then dried at $60^{\circ} \mathrm{C}$ for $24 \mathrm{~h}$. The concentrations of $\mathrm{Cu}, \mathrm{Pb}, \mathrm{Zn}, \mathrm{Ni}, \mathrm{Mn}, \mathrm{Fe}, \mathrm{As}$, $\mathrm{Cd}, \mathrm{Cr}$, and $\mathrm{Hg}$ were measured in the digested phase by inductively coupled plasma mass spectrometry (ICP-MS; ACME Analytical Labs, Vancouver, BC, Canada). The prepared sample was digested with a modified aqua regia solution with equal parts of concentrated $\mathrm{HCl}, \mathrm{HNO}_{3}$, and $\mathrm{DI} \mathrm{H}_{2} \mathrm{O}$ for $1 \mathrm{~h}$ in a heating block. The sample was made up to volume with dilute $\mathrm{HCl}$. Quality control was performed using duplicates, blanks, and internal standard reference material (DS 9) obtained from ACME Analytical Labs. The values obtained ( $\mathrm{mg} \mathrm{kg}^{-1}$ ) from the analysis of this sample were as follows:

\begin{tabular}{cccc}
\hline Element & Observed & Permissible & Detection limits \\
\hline $\mathrm{Cu}$ & 104 & 108 & 0.01 \\
$\mathrm{~Pb}$ & 118 & 126 & 0.01 \\
$\mathrm{Zn}$ & 319.6 & 317 & 0.1 \\
$\mathrm{Ni}$ & 38.7 & 40.3 & 0.1 \\
$\mathrm{Mn}$ & 575 & 575 & 1 \\
$\mathrm{Fe}$ & 23.000 & 23.300 & 100 \\
$\mathrm{As}$ & 25 & 25.5 & 0.1 \\
$\mathrm{Cd}$ & 2.41 & 2.40 & 0.01 \\
$\mathrm{Cr}$ & 110.7 & 121 & 0.5 \\
$\mathrm{Hg}$ & 0.0203 & 0.0200 & 0.005 \\
\hline
\end{tabular}

Two indices, EF and CF, were used to assess metal accumulation in the sediment. The former is calculated by dividing the current metal/Al weight ratio by the background metal/Al ratio (Acevedo-Figueroa et al. 2006; Çevik et al. 2009; Vrhovnik et al. 2013). In this way, the anthropogenic effect can be determined by detecting an increase exceeding the background value. The obtained values were evaluated according to the procedure described by Sutherland (2000): $E F<$ 2, $E F=2-5, E F=5-20, E F=20-40$, and $E F>40$ indicate no, moderate, significant, very high, and excessive enrichment, respectively. Further, $C F$ is the ratio of the current metal content in the existing sediment to the normal permissible concentration levels. Thus, metal enrichment in the sediment is assessed. CF was calculated according to the method employed by Håkanson (1980), and $C F<1,1 \leq C F<3,3 \leq C F<6$, and $C F>6$ indicate low, moderate, high, and very high contamination, respectively.

To determine environmental quality of the sediment, an integrated Pollution Load Index (PLI) was used, according to Suresh et al. (2011):

$$
P L I=\left(C F_{1} \times C F_{2} \times \ldots C F_{n}\right)^{1 / n}
$$

where CF is the contamination factor and $n$ is the number of elements used. A PLI value of 0 indicates a clean area, while a value of up to 1 indicates pollution. The $R I$ defined by Håkanson (1980) was used to draw inferences about the toxic effects of metals. The $R I$ values for each metal $\left(E_{r}^{i}\right)$ and an integrated value for all metals are interpreted as follows:

$E_{r}^{i}<40,40 \leq E_{r}^{i}<80,80 \leq E_{r}^{i}<160,160 \leq E_{r}^{i}<320$, and $E_{r}^{i} \geq 320$

indicate low, moderate, significant, high, and very high potential ecological risk, respectively. It is calculated using the following formula presented by Håkanson (1980):

$$
E_{r}^{i}=C_{f}^{i} \times T_{f}^{i}
$$

where $T_{f}^{i}$ is the toxicity coefficient for a single metal, and $C_{f}^{i}$ is the ratio between the metal content in

Table 1

\begin{tabular}{|c|c|c|c|c|}
\hline Sites & \multicolumn{2}{|c|}{ Coordinates } & General characteristics & $\begin{array}{c}\text { Depth } \\
(\mathrm{m})\end{array}$ \\
\hline 1 & $36^{\circ} 39^{\prime} 39^{\prime \prime} \mathrm{N}$ & $36^{\circ} 12^{\prime} 46^{\prime \prime} \mathrm{E}$ & $\begin{array}{l}\text { The site is located in an industrial zone, } 11 \mathrm{~km} \text { from Iskenderun. The region is located near heavy indus- } \\
\text { trial facilities. }\end{array}$ & 2.5 \\
\hline 2 & $36^{\circ} 38^{\prime} 06^{\prime \prime} \mathrm{N}$ & $36^{\circ} 12^{\prime} 10^{\prime \prime} \mathrm{E}$ & The site is located $8 \mathrm{~km}$ from Iskenderun. & 3 \\
\hline 3 & $36^{\circ} 27^{\prime} 12^{\prime \prime} \mathrm{N}$ & $35^{\circ} 55^{\prime} 35^{\prime \prime} \mathrm{E}$ & $\begin{array}{l}\text { The region is located near agricultural land and tourist activities. In the western part of the site there is } \\
\text { a small stream that drains into the sea. }\end{array}$ & 2 \\
\hline 4 & $36^{\circ} 21^{\prime} 40^{\prime \prime} \mathrm{N}$ & $35^{\circ} 49^{\prime} 23^{\prime \prime} \mathrm{E}$ & The site is located $48 \mathrm{~km}$ from Iskenderun and $11 \mathrm{~km}$ from Arsuz, and away from the industrial area. & 3 \\
\hline 5 & $36^{\circ} 51^{\prime} 00^{\prime \prime} \mathrm{N}$ & $35^{\circ} 54^{\prime} 41^{\prime \prime} \mathrm{E}$ & $\begin{array}{l}\text { The site is located in the Yumurtalık Gölovası region, which is located near a thermal power plant and a } \\
\text { terminal where oil transportation is carried out. }\end{array}$ & 11 \\
\hline 6 & $36^{\circ} 51^{\prime} 08^{\prime \prime} \mathrm{N}$ & $35^{\circ} 54^{\prime} 54^{\prime \prime} \mathrm{E}$ & The site is located near a thermal power plant and a terminal where oil transportation is carried out. & 8 \\
\hline 7 & $36^{\circ} 50^{\prime} 40^{\prime \prime} \mathrm{N}$ & $35^{\circ} 55^{\prime} 12^{\prime \prime} \mathrm{E}$ & The site is located near a thermal power plant and a terminal where oil transportation is carried out. & 25 \\
\hline 8 & $36^{\circ} 51^{\prime} 16^{\prime \prime} \mathrm{N}$ & $35^{\circ} 54^{\prime} 43^{\prime \prime} \mathrm{E}$ & The site is located near a thermal power plant and a terminal where oil transportation is carried out. & 7 \\
\hline
\end{tabular}

Iskenderun Bay sampling sites 
the sediment at a given site and the background concentration levels. Depending on the toxicity, the corresponding coefficients are as follows: $\mathrm{Hg}=40, \mathrm{Cd}$ $=30, \mathrm{As}=10, \mathrm{Cu}=\mathrm{Pb}=\mathrm{Ni}=5, \mathrm{Cr}=2$, and $\mathrm{Zn}=1$ (Guo et al. 2010).

Further, the $R l$ is calculated as follows:

$$
R I=\sum E_{r}^{i}
$$

and $R I<150,150 \leq R I<300,300 \leq R I<600$, and $R I \geq$ 600 indicate low, moderate, significant, and very high ecological risk, respectively.

In addition, Pearson's correlation analysis was used to analyze the relationships between the variables. Further, CA was used to determine the distance between the variables. PCA was employed to identify the main sources of variation between the study sites in the bay.

\section{Results and discussion}

\subsection{Heavy metal distributions}

The concentration of heavy metals in the sediments is presented in Table $2\left(\mathrm{mg} \mathrm{kg}^{-1}\right)$. According to the results, the concentrations are in the following order: $\mathrm{Fe}>\mathrm{Ni}>\mathrm{Mn}>\mathrm{Cr}>\mathrm{Zn}>\mathrm{Cu}>\mathrm{As}>\mathrm{Pb}>\mathrm{Cd}>\mathrm{Hg}$.

$\mathrm{Ni}, \mathrm{Mn}, \mathrm{As}, \mathrm{Cd}$, and $\mathrm{Cr}$ were found to be present in concentrations higher than their corresponding values in the upper layer of the Earth's crust. In addition, the concentrations of $\mathrm{As}, \mathrm{Ni}$, and $\mathrm{Cr}$ were higher than those in other study areas (Yalcin et al. 2019). All As and Cd concentrations, except for the shale value, are higher than the values for sand sediment, sandstone, and the upper crust of the Earth (Table 3). According to the United States Environmental Protection Agency (EPA 1995), the sediment values indicate moderate $\mathrm{Cu}$ pollution, heavy $\mathrm{Ni}$ and Fe pollution, and moderate to heavy As and $\mathrm{Cr}$ pollution (Table 4).

The $E F$ value changes depending on the difference in the grain size of metals, so it was fixed by normalization with Al values. In this way, a more accurate result of enrichment can be obtained. The average $E F$ values of the studied metals in Iskenderun Bay are in the following order: $\mathrm{Ni}>\mathrm{As}>\mathrm{Cr}>\mathrm{Cd}>$ $\mathrm{Zn}>\mathrm{Pb}>\mathrm{Cu}>\mathrm{Mn}$ (Table 4). In general, the highest enrichment values were obtained for Site 4 . Cu values showed minimal enrichment at Sites 1 and 3 . Pb and $\mathrm{Zn}$ values showed no enrichment at any site. $\mathrm{Ni}$ showed moderate enrichment at Sites 4, 5, 6, 7, and 8 , significant enrichment at Sites 1 and 2, and a very high level of enrichment at Sites 3 and 4. Mn showed minimal enrichment at all sites. Further, there was significant As pollution at all sites. $\mathrm{Cd}, \mathrm{Cr}$, and $\mathrm{Hg}$ showed no significant increase (Table 5). These results indicate an anthropogenic origin of the heavy metals, which is of great concern for the ecosystem. If $2>E F$ $>1.5$, metals originate from natural sources (Garcia et al. 2008; Alharbi \& El-Sorogy 2017). If $E F>1.5$ or 2 , metals come from anthropogenic sources (Garcia et al. 2008). $\mathrm{Cr}, \mathrm{Cu}, \mathrm{Hg}, \mathrm{Ni}$, and $\mathrm{Zn}$ are known to be of non-anthropogenic origin. However, among these metals, $\mathrm{Ni}$ is of high value. It can come from natural and anthropogenic sources. Further, it is one of the main trace elements of crude oil and is widely used. It has a wide range of applications, especially in $\mathrm{Ni}-\mathrm{Cd}$ rechargeable batteries. High concentrations in the marine environment result from fuel pollution. Various As compounds are used as fertilizers, especially in agricultural fields. As is also used in agricultural pesticides to kill ants, to protect cotton seeds from insects, and for protective purposes in the timber industry (Data et al. 2004; Lollar 2005). The presence of intensive agricultural and industrial areas in the region of Iskenderun Bay may cause high As concentrations in the sediments. The results also suggest that $\mathrm{Ni}, \mathrm{As}$, and $\mathrm{Cr}$ have the same anthropogenic origin.

Table 2

\begin{tabular}{|c|c|c|c|c|c|c|c|c|}
\hline Site No. & 1 & 2 & 3 & 4 & 5 & 6 & 7 & 8 \\
\hline $\mathrm{Cu}$ & 12.68 & 11.32 & 10.32 & 11.47 & 11.15 & 11.28 & 25.39 & 9.66 \\
\hline $\mathrm{Pb}$ & 10.40 & 9.80 & 2.11 & 2.73 & 5.57 & 5.81 & 12.93 & 5.20 \\
\hline $\mathrm{Zn}$ & 39.7 & 39.8 & 26.3 & 23.9 & 31.0 & 30.8 & 70.6 & 27.6 \\
\hline $\mathrm{Ni}$ & 797.7 & 848.0 & 1673.6 & 1460 & 115.7 & 132.9 & 252.6 & 104.8 \\
\hline $\mathrm{Mn}$ & 494 & 535 & 738 & 504 & 699 & 750 & 649 & 719 \\
\hline $\mathrm{Fe}$ & 31300 & 32000 & 38800 & 36700 & 19900 & 19900 & 30200 & 17300 \\
\hline As & 6.9 & 7.5 & 13.3 & 16.7 & 15.3 & 16.0 & 10.0 & 14.3 \\
\hline $\mathrm{Cd}$ & 0.14 & 0.13 & 0.03 & 0.03 & 0.10 & 0.10 & 0.17 & 0.12 \\
\hline $\mathrm{Cr}$ & 478.4 & 515.8 & 224.6 & 353.5 & 68.2 & 73.3 & 138.5 & 70 \\
\hline $\mathrm{Hg}$ & 0.034 & 0.028 & 0.005 & 0.005 & 0.012 & 0.014 & 0.045 & 0.01 \\
\hline
\end{tabular}


Table 3

Descriptive and background level values of the variables $\left(\mathrm{mg} \mathrm{kg}^{-1}\right)$

\begin{tabular}{|l|c|c|c|c|c|c|c|c|c|c|}
\hline & $\mathrm{Cu}$ & $\mathrm{Pb}$ & $\mathrm{Zn}$ & $\mathrm{Ni}$ & $\mathrm{Mn}$ & $\mathrm{Fe}$ & $\mathrm{As}$ & $\mathrm{Cd}$ & $\mathrm{Cr}$ & $\mathrm{Hg}$ \\
\hline Heavy metal Av. & 12.90 & 6.81 & 36.21 & 673.26 & 636.0 & 28262 & 12.5 & 0.10 & 240.2 \\
\hline Iskenderun Gulf & 16.77 & 15.72 & 89.15 & 646.14 & 1166.3 & & 9.75 & 0.26 & 1687.2 \\
\hline Ambarlı Port & 280 & 96 & 346 & & & & 53 & \\
\hline Laizhou Bay & 22 & 21.9 & 60.4 & & & & & 0.12 & 60 \\
\hline Liaodon Bay & 19.4 & 31.8 & 71.7 & 22.5 & & & & 1.2 & 46.4 & \\
\hline Coastal Bohai Bay & 38.5 & 34.7 & 131.1 & 40.7 & & & & 0.22 & 101.4 \\
\hline Interdial Bohai Bay & 24 & 21.11 & 89.60 & 41.35 & & & & 0.12 & 68.6 & \\
\hline Al-khobar Area & 330 & 9.4 & 86 & 116 & 244 & 16.73 & & 3.1 & 83 & 1.61 \\
\hline Standard error & 5.11 & 3.83 & 15.06 & 629.01 & 108.7 & 8187 & 3.85 & 0.05 & 186.1 & 0.01 \\
\hline Sand Sediment & 40.00 & 17.00 & 65.00 & 40.0 & 680.0 & 19.22 & - & - & 74.00 & 650 \\
\hline Sandstone & 9.00 & 7.00 & 16.00 & 2.00 & 90.00 & 1 & 1.00 & 0.09 & 35.00 & 240 \\
\hline Shale & 45.00 & 20.00 & 95.00 & 50.00 & 85.00 & & 13.0 & 0.30 & 90.00 & \\
\hline Upper crust & 25.00 & 16.00 & 71.00 & 50.00 & 600.0 & & 1.50 & 0.001 & 85.00 \\
\hline Soil & 21.00 & 14.00 & 94.00 & 24.00 & 600.0 & & 7.40 & 0.34 & 64.00 & \\
\hline TEL & 19 & 30.2 & 124 & 15.9 & & & 7.2 & 0.68 & 52.3 & 0.70 \\
\hline PEL & 110 & 110 & 270 & 42.8 & & & 42 & 4.2 & 160 \\
\hline
\end{tabular}

Table 4

Sediment values according to EPA

\begin{tabular}{|c|}
\hline Metal $\left(\mathrm{mg} \mathrm{kg}^{-1}\right)$ \\
\hline $\mathrm{Cu}$ \\
\hline $\mathrm{Pb}$ \\
\hline $\mathrm{Zn}$ \\
\hline $\mathrm{Ni}$ \\
\hline $\mathrm{Mn}$ \\
\hline $\mathrm{Fe}$ \\
\hline $\mathrm{As}$ \\
\hline $\mathrm{Cd}$ \\
\hline $\mathrm{Cr}$ \\
\hline $\mathrm{Hg}$
\end{tabular}

Not polluted
$\quad<25$
$<40$
$<90$
$<20$
$<300$
$<17000$
$<3$
-
$<25$
$<1$

\begin{tabular}{|c|}
\hline Moderately polluted \\
\hline $25-30$ \\
$40-60$ \\
$90-200$ \\
$20-50$ \\
$300-500$ \\
$17000-25000$ \\
$3-8$ \\
- \\
$25-75$ \\
$>-1$
\end{tabular}

$\begin{aligned} & \text { Heavily pollute } \\ & \quad>50 \\ &>60 \\ &> 200 \\ &>50 \\ &>500 \\ &> 25000 \\ &>8 \\ &>6 \\ &>75 \\ &>1\end{aligned}$

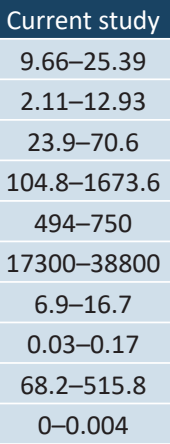

Table 5

Enrichment factor $(E F)$ measured in Iskenderun Bay

\begin{tabular}{|c|}
\hline Site No. \\
\hline $\mathrm{Cu}$ \\
\hline $\mathrm{Pb}$ \\
\hline $\mathrm{Zn}$ \\
\hline $\mathrm{Ni}$ \\
\hline $\mathrm{Mn}$ \\
\hline $\mathrm{As}$ \\
\hline $\mathrm{Cd}$ \\
\hline $\mathrm{Cr}$ \\
\hline $\mathrm{Hg}$ \\
\hline
\end{tabular}

\begin{tabular}{|c|c|c|c|}
\hline 1 & 2 & 3 & 4 \\
\hline 0.42 & 0.36 & 0.27 & 3.22 \\
\hline 0.78 & 0.71 & 0.12 & 0.17 \\
\hline 0.62 & 0.61 & 0.33 & 0.32 \\
\hline 17.6 & 18.3 & 29.8 & 27.5 \\
\hline 0.00 & 0.00 & 0.00 & 0.00 \\
\hline 5.75 & 6.11 & 8.95 & 11.8 \\
\hline 1.05 & 0.95 & 0.18 & 0.19 \\
\hline 7.98 & 8.41 & 3.02 & 5.03 \\
\hline 0.12 & 0.10 & 0.01 & 0.01 \\
\hline
\end{tabular}

\begin{tabular}{|c|}
\hline 5 \\
\hline 0.58 \\
\hline 0.65 \\
\hline 0.77 \\
\hline 4.01 \\
\hline 0.00 \\
\hline 20.0 \\
\hline 1.18 \\
\hline 1.78 \\
\hline 0.07 \\
\hline
\end{tabular}

\begin{tabular}{|c|}
\hline 6 \\
\hline 0.59 \\
\hline 0.68 \\
\hline 0.76 \\
\hline 4.61 \\
\hline 0.00 \\
\hline 20.9 \\
\hline 1.18 \\
\hline 1.92 \\
\hline 0.08 \\
\hline
\end{tabular}

\begin{tabular}{|c|c|c|}
\hline 7 & 8 & Ave. \\
\hline 0.87 & 0.58 & 0.50 \\
\hline 1.00 & 0.70 & 0.60 \\
\hline 1.15 & 0.78 & 0.67 \\
\hline 5.78 & 4.18 & 13.98 \\
\hline 0.00 & 0.00 & 0.00 \\
\hline 8.64 & 21.5 & 13.00 \\
\hline 1.32 & 1.63 & 0.96 \\
\hline 2.39 & 2.11 & 4.08 \\
\hline 0.17 & 0.06 & 0.08 \\
\hline
\end{tabular}

The $C F$ values, used to predict metal sources, are in the following order: $\mathrm{As}>\mathrm{Ni}>\mathrm{Cd}>\mathrm{Cr}>\mathrm{Fe}>\mathrm{Cu}>\mathrm{Pb}>$ $\mathrm{Hg}$. Consistent with these values, low accumulation of $\mathrm{Cu}, \mathrm{Pb}, \mathrm{Zn}, \mathrm{Mn}, \mathrm{Fe}, \mathrm{Cd}$, and $\mathrm{Hg}$ was observed at all sites. Moderate $\mathrm{Cr}$ contamination was generally observed, except at Sites 5 and 6 where low contamination was detected. Moderate $\mathrm{Ni}$ accumulation was observed at Sites 5 and 6 . High Ni contamination was observed at Site 7 and very high contamination was observed at Sites 1, 2, 3, and 4. Moreover, although moderate 
contamination was observed for all metals at some sites, $C F$ values were close to values corresponding to high contamination at Sites 3 and 4 (Table 6).

Table 6

$\overline{\text { Contamination factor (CF) and pollution load index (PLI) }}$ values in Iskenderun Bay

\begin{tabular}{|c|c|c|c|c|c|c|c|c|}
\hline $\begin{array}{c}\text { Site } \\
\text { No. }\end{array}$ & 1 & 2 & 3 & 4 & 5 & 6 & 7 & 8 \\
\hline $\mathrm{Cu}$ & 0.28 & 0.25 & 0.22 & 0.25 & 0.24 & 0.25 & 0.56 & 0.21 \\
\hline $\mathrm{Pb}$ & 0.52 & 0.49 & 0.10 & 0.13 & 0.27 & 0.29 & 0.64 & 0.26 \\
\hline $\mathrm{Zn}$ & 0.41 & 0.41 & 0.27 & 0.25 & 0.32 & 0.32 & 0.74 & 0.29 \\
\hline $\mathrm{Ni}$ & 11.7 & 12.4 & 24.6 & 21.4 & 1.70 & 1.95 & 3.71 & 1.54 \\
\hline $\mathrm{Mn}$ & 0.58 & 0.62 & 0.86 & 0.59 & 0.82 & 0.88 & 0.76 & 0.84 \\
\hline $\mathrm{Fe}$ & 0.66 & 0.68 & 0.82 & 0.78 & 0.42 & 0.42 & 0.64 & 0.36 \\
\hline $\mathrm{As}$ & 3.83 & 4.16 & 7.38 & 9.27 & 8.50 & 8.88 & 5.55 & 7.94 \\
\hline $\mathrm{Cd}$ & 0.7 & 0.65 & 0.15 & 0.15 & 0.5 & 0.5 & 0.85 & 0.65 \\
\hline $\mathrm{Cr}$ & 5.31 & 5.73 & 2.49 & 3.92 & 0.75 & 0.81 & 1.53 & 0.77 \\
\hline $\mathrm{Hg}$ & 0.08 & 0.07 & 0.01 & 0.01 & 0.03 & 0.03 & 0.11 & 0.02 \\
\hline $\mathrm{PLI}$ & 0.11 & 0.09 & 0.0 & 0.0 & 0.0 & 0.0 & 0.16 & 0.0 \\
\hline
\end{tabular}

The $P L /$ values are presented in Table 6. They range between 0.00 and 0.16 , with an average value of 0.045 . The ideal $P L /$ value is zero, which indicates no pollution in the environment and $>1$ indicates progressive pollution (Chakravarty \& Patgiri 2009). Values close to zero indicate that no pollution was detected in the sediments of Iskenderun Bay. The $R /$ values calculated for each individual metal and the integrated value for all metals show the total potential impact of all metals (Table 6). The order of the calculated $R /$ values of metals is as follows: As $>\mathrm{Ni}>\mathrm{Cd}>\mathrm{Cr}>\mathrm{Hg}>\mathrm{Pb}>$ $\mathrm{Cu}>\mathrm{Zn}$. Further, the average $\mathrm{Rl}$ values of all metals other than $\mathrm{Ni}$ and $\mathrm{As}$ do not exceed the maximum limit of 40 , which indicates low ecological risk. Further, the ecological risk associated with all metals is low at all sites. Although the risk associated with $\mathrm{Ni}$ is below the limit at Sites 5, 6, 7, and 8, and the risk associated with As is above the limit at all sites, this does not represent a hazard.
Further, the highest integrated $R I$ value for all metals was recorded at Site 4, followed closely by Site 3 (Table 7). The lowest $R I$ value was found at Site 8 . The ecological risk was found to be low because the $R /$ value did not exceed $>150$ for Sites 1, 2, 5, 6, and 7 . Moderate potential ecological risk was calculated for Sites 3 and 4, i.e. $150 \leq R l<300$ (Håkanson 1980). The mean Igeo values of the surface sediment metals were as follows: $\mathrm{Fe}>\mathrm{Mn}>\mathrm{Zn}>\mathrm{Cu}>\mathrm{As}>\mathrm{Pb}>\mathrm{Ni}>\mathrm{Cd}>$ $\mathrm{Hg}>\mathrm{Cr}$. The $\mathrm{I}_{\text {geo }}$ values for Fe and $\mathrm{Mn}$ indicate extreme contamination. Further, very high contamination due to $\mathrm{Zn}$, high contamination due to $\mathrm{Cu}$ and $\mathrm{As}$, while moderate contamination due to $\mathrm{Pb}$ was detected. No pollution due to $\mathrm{Cr}, \mathrm{Hg}, \mathrm{Cd}$, and $\mathrm{Ni}$ was found (Table 8).

\subsection{Multivariate statistical analysis}

\subsubsection{Pearson's correlation analysis}

Although Pearson's correlation analysis carried out to determine the correlation between variables indicated that many metals are correlated, $\mathrm{Ni}, \mathrm{Mn}, \mathrm{As}$, and $\mathrm{Cr}$ showed no correlation with any other metals. $\mathrm{Fe}$ and $\mathrm{Mn}$ are highly correlated with all metals except $\mathrm{Pb}$ and $\mathrm{Cd}$, and $\mathrm{Al}$ is highly correlated with all metals except $\mathrm{Pb}, \mathrm{Cd}$, and $\mathrm{Hg}$. This indicates that the transport mechanisms of $\mathrm{Pb}$ and $\mathrm{Cd}$ are different from those of other elements. The greatest contribution to PER comes from $\mathrm{Pb}, \mathrm{Ni}$, and $\mathrm{Hg}$, while $\mathrm{Zn}$ and $\mathrm{As}$ are the major contributors to PLI. Correlations for detailed comparisons are given in Table 9.

\subsubsection{Cluster analysis}

CA was performed to identify the relationships between the variables and clustering of the variables. According to the clustering dendrogram, three large clusters can be distinguished (Fig. 2). The first cluster contains $\mathrm{Cu}, \mathrm{Zn}, \mathrm{Pb} \mathrm{Hg}, \mathrm{Cd}$, and Al. This indicates that the transport mechanisms and/or sources of these

Table 7

Potential ecological index $(\mathrm{RI})$ for a single metal $\left(\mathrm{E}_{-} \mathrm{f} \wedge \mathrm{i}\right)$

\begin{tabular}{|c|c|c|c|c|c|c|c|c|c|c|}
\hline Site No. & $\mathrm{Cu}$ & $\mathrm{Pb}$ & $\mathrm{Zn}$ & $\mathrm{Ni}$ & $\mathrm{As}$ & $\mathrm{Cd}$ & $\mathrm{Cr}$ & $\mathrm{Hg}$ & $\mathrm{RI}$ \\
\hline 1 & 1.40 & 2.60 & 0.41 & 58.66 & 38.33 & 21 & 10.63 & 3.40 & 136.46 \\
\hline 2 & 1.25 & 2.45 & 0.41 & 62.35 & 41.66 & 19.5 & 11.46 & 2.80 & 141.91 \\
\hline 3 & 1.14 & 0.52 & 0.27 & 123.05 & 73.88 & 4.5 & 4.99 & 0.50 & 208.89 \\
\hline 4 & 1.27 & 0.68 & 0.25 & 107.39 & 92.77 & 4.5 & 7.85 & 0.50 & 215.24 \\
\hline 5 & 1.23 & 1.39 & 0.32 & 8.50 & 85.00 & 15.0 & 1.51 & 1.20 & 114.18 \\
\hline 6 & 1.25 & 1.45 & 0.32 & 9.77 & 88.88 & 42 & 1.62 & 1.40 & 119.72 \\
\hline 7 & 2.82 & 3.23 & 0.74 & 18.57 & 55.55 & 25.5 & 3.07 & 4.50 & 114.00 \\
\hline 8 & 1.07 & 1.30 & 0.29 & 7.70 & 79.44 & 18 & 1.55 & 1.00 & 110.37 \\
\hline Average & 1.43 & 1.70 & 0.38 & 49.05 & 69.44 & 15.37 & 5.33 & 1.91 & 145.09 \\
\hline
\end{tabular}


Table 8

Geoaccumulation $\left(\mathrm{I}_{\mathrm{geo}}\right)$ values for the sampling sites

\begin{tabular}{|c|c|c|c|c|c|c|c|c|c|c|}
\hline \multirow{2}{*}{ Site No. } & \multicolumn{10}{|c|}{$\mathrm{I}_{\text {geo }}$} \\
\hline & $\mathrm{Cu}$ & $\mathrm{Pb}$ & $\mathrm{Zn}$ & $\mathrm{Ni}$ & $\mathrm{Mn}$ & $\mathrm{Fe}$ & As & $\mathrm{Cd}$ & $\mathrm{Cr}$ & $\mathrm{Hg}$ \\
\hline 1 & 3.58 & 1.67 & 3.82 & -0.83 & 7.97 & 12.03 & 2.12 & -3.24 & -6.96 & -6.9 \\
\hline 2 & 2.61 & 1.77 & 3.91 & -0.76 & 8.06 & 12.17 & 2.22 & -3.29 & -7.09 & -6.7 \\
\hline 3 & 1.48 & 0.31 & 2.56 & -37.4 & 6.33 & 7.37 & 0.93 & -5.25 & -8.49 & -8.3 \\
\hline 4 & 2.66 & 1.04 & 3.77 & -6.74 & 8.08 & 12.10 & 2.61 & -5.13 & -2.08 & -7.9 \\
\hline 5 & 2.78 & 1.79 & 4.08 & 5.71 & 8.51 & 12.89 & 2.83 & -3.54 & 10.8 & -6.9 \\
\hline 6 & 2.81 & 1.84 & 4.11 & -5.79 & 8.47 & 12.94 & 2.88 & -3.53 & -11.3 & -6.7 \\
\hline 7 & 3.80 & 2.82 & 5.06 & 6.62 & 8.81 & 13.73 & 2.92 & -2.75 & -11.6 & -5.5 \\
\hline 8 & 2.55 & 1.62 & 3.87 & 5.49 & 8.23 & 12.66 & 2.62 & -3.36 & -14.3 & -7.1 \\
\hline Mean & 2.78 & 1.61 & 3.90 & -2.76 & 8.06 & 11.99 & 2.39 & -3.76 & -9.10 & -7.0 \\
\hline
\end{tabular}

Table 9

Pearson's correlation coefficients between variables (boldface figures represent statistically significant correlations at $95 \%$ confidence interval)

\begin{tabular}{|c|c|c|c|c|c|c|c|c|c|c|c|c|}
\hline & $\mathrm{Cu}$ & $\mathrm{Pb}$ & $\mathrm{Zn}$ & $\mathrm{Ni}$ & $\mathrm{Mn}$ & $\mathrm{Fe}$ & As & $\mathrm{Cd}$ & $\mathrm{Cr}$ & $\mathrm{Hg}$ & PER & $P L I$ \\
\hline $\mathrm{Cu}$ & 1 & & & & & & & & & & & \\
\hline $\mathrm{Pb}$ & $0.71^{*}$ & & & & & & & & & & & \\
\hline $\mathrm{Zn}$ & $0.94^{* *}$ & $0.88^{* *}$ & & & & & & & & & & \\
\hline $\mathrm{Ni}$ & -024 & -0.43 & -0.33 & & & & & & & & & \\
\hline $\mathrm{Mn}$ & -0.07 & -0.34 & -0.12 & -0.39 & & & & & & & & \\
\hline $\mathrm{Fe}$ & 0.14 & -0.06 & 0.858 & $0.91^{* *}$ & -0.51 & & & & & & & \\
\hline As & -0.33 & $-0.78^{*}$ & -0.57 & -0.05 & 0.51 & -0.31 & & & & & & \\
\hline $\mathrm{Cd}$ & 0.57 & $0.92^{* *}$ & $0.76^{*}$ & -0.70 & -0.10 & -0.41 & -0.63 & & & & & \\
\hline $\mathrm{Cr}$ & -0.11 & 0.26 & 001 & 0.58 & -0.87 & 0.66 & -066 & 0.0 & & & & \\
\hline $\mathrm{Hg}$ & $0.77^{*}$ & $0.98^{* *}$ & 0.91 & -0.31 & -0.36 & 0.07 & -0.79 & $0.86^{* *}$ & 0.29 & & & \\
\hline
\end{tabular}

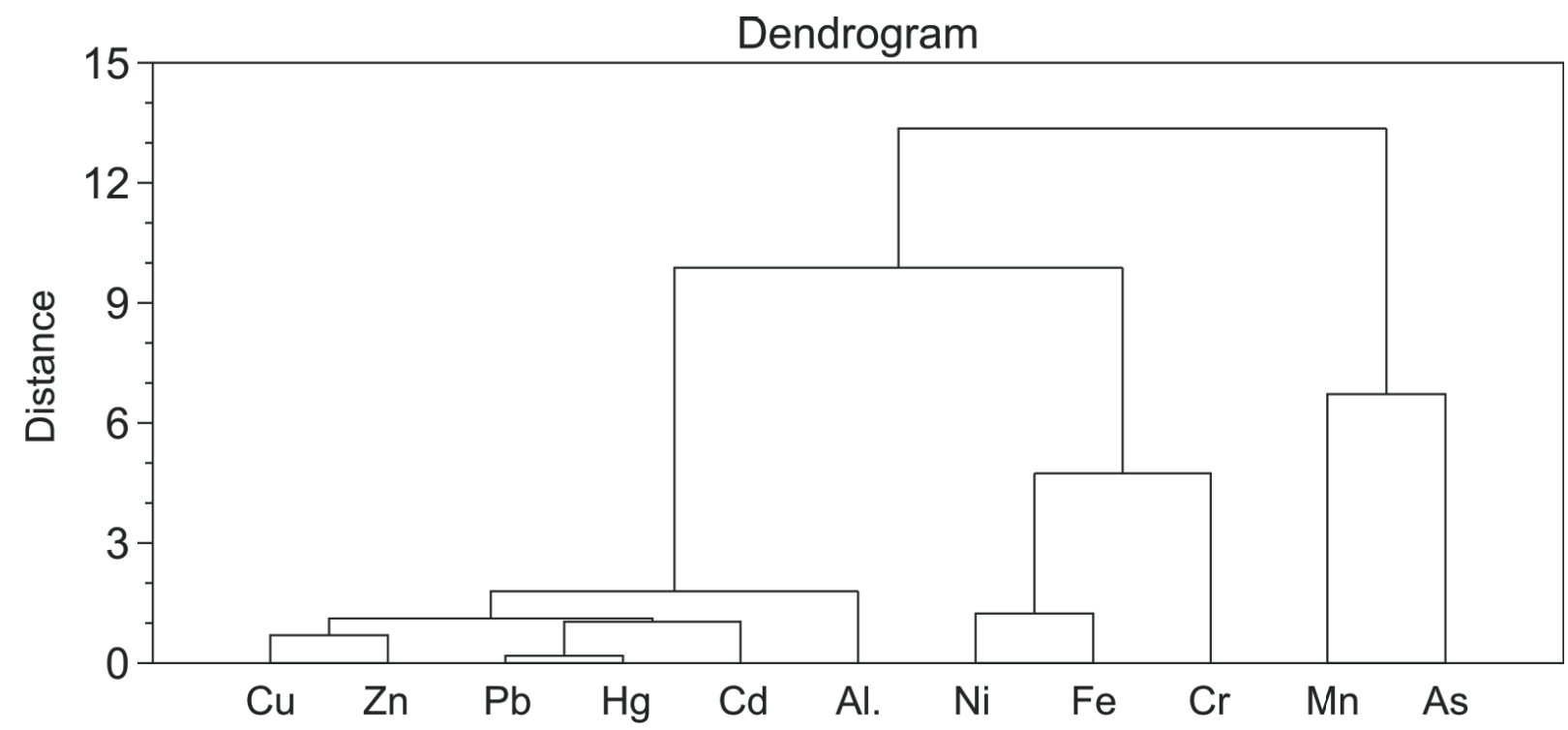

Figure 2

Similarity analysis for the heavy metals 
elements are similar. The second group consists of $\mathrm{Ni}$, $\mathrm{Fe}$, and $\mathrm{Cr}$. The third one consists of $\mathrm{Mn}$ and $\mathrm{As}$ and is located further away from the two other groups (Fig. 3).

Table 10 presents the results of PCA. A total of $94.5 \%$ of the data variance was explained by three principle components: $\mathrm{PC} 1$ ( $\mathrm{Pb}, \mathrm{ZN}, \mathrm{Al}, \mathrm{Hg}$ ) accounted for $51 \%$ of the total variance, PC2 (Fe and As) - 31\% of the variance; and $\mathrm{PC} 3(\mathrm{Cu}, \mathrm{Ni}$, and $\mathrm{Fe})-11.2 \%$. Iskenderun Bay is dominated by currents coming from the coasts of Israel, Lebanon, and Syria, due to the bay's connection with the open sea. Further, the bay is affected by two cyclonic wind systems: one of them is clockwise and the other one is counterclockwise. Recently, Iskenderun Bay has experienced serious pollution problems as a result of rapid population growth and unplanned urbanization in parallel to industrialization. Pollution is at a critical level due to large industrial plants located along the coastal areas of Iskenderun Bay. These industrial plants are iron and steel plants, fertilizer plants, industrial factories, oil transportation, liquid gas, and coal transportation (Özcan et al. 2010). In addition, agricultural pollutants and household waste transported by the Seyhan, Ceyhan and Orontes rivers reach the bay region. Further, we found that $\mathrm{As}, \mathrm{Ni}$, and Fe concentrations exceed the acceptable limits due to waste coming from iron and steel plants, agricultural land, and industrial areas.

The content of heavy metals and potential ecological risks were studied using sediment samples
Table 10

Principal Component Analysis (PCA)

\begin{tabular}{|l|c|c|c|}
\hline & PC1 & PC2 & PC3 \\
\hline $\mathrm{Cu}$ & 0.34 & 0.02 & $\mathbf{0 . 4 9}$ \\
\hline $\mathrm{Pb}$ & $\mathbf{0 . 4 0}$ & -0.06 & -0.14 \\
\hline $\mathrm{Zn}$ & $\mathbf{0 . 3 9}$ & -0.00 & 0.27 \\
\hline $\mathrm{Ni}$ & -0.20 & -0.42 & $\mathbf{0 . 3 2}$ \\
\hline $\mathrm{Mn}$ & -0.10 & $\mathbf{0 . 4 2}$ & 0.15 \\
\hline $\mathrm{Fe}$ & -0.03 & -0.45 & $\mathbf{0 . 4 4}$ \\
\hline $\mathrm{As}$ & -0.27 & $\mathbf{0 . 3 1}$ & 0.29 \\
\hline $\mathrm{Cd}$ & 0.38 & 0.09 & -0.31 \\
\hline $\mathrm{Cr}$ & 0.04 & -0.50 & -0.23 \\
\hline $\mathrm{Al}$ & $\mathbf{0 . 3 3}$ & 0.21 & 0.30 \\
\hline $\mathrm{Hg}$ & $\mathbf{0 . 4 0}$ & -0.10 & -0.02 \\
\hline Eigenvalue & 5.71 & 3.48 & 1.23 \\
\hline \% Variance & 51.96 & 31.64 & 11.29 \\
\hline \% Clustering & 51.96 & 83.60 & 1.23 \\
\hline
\end{tabular}

collected from eight sampling sites in Iskenderun Bay. $E F$ and $C F$ values indicated significant to moderate accumulation of metals. Although the calculated ecological risk associated with $\mathrm{As}$ and $\mathrm{Ni}$ was high at some sites, it was generally below the limit. The integrated $R I$ value for all metals indicates a moderate potential ecological risk at Sites 3 and 4 . The results of the assessment showed that the current concentrations of the metals studied in Iskenderun Bay do not pose a risk to the ecosystem. Further, As and $\mathrm{Ni}$ with the highest ecological risk values are not correlated with other elements because they reach

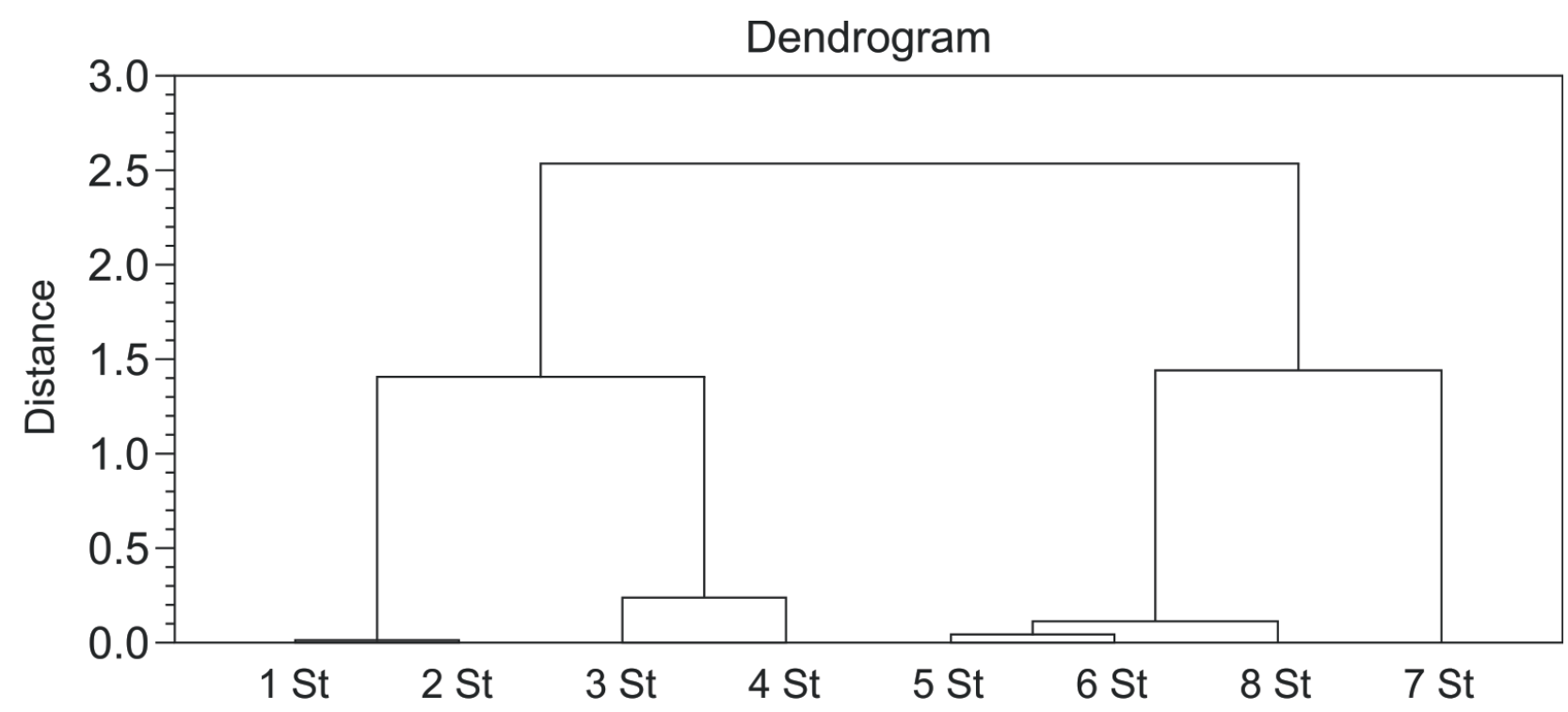

Figure 3

Similarity analysis for the study sites 
the ecosystem through different pathways. Moreover, $\mathrm{Cd}$ and $\mathrm{Hg}$ concentrations are at the maximum limits and should be prevented from increasing further, so that the ecosystem is protected for the future of the Bay. The high levels of all environmental and ecological indices may be associated with the presence of industrial facilities, thermal power plants, and agricultural land near the bay and the fact that it is a pollution discharge area. In the future, necessary measures to protect the bay from industrial pollution should be considered.

The content of heavy metals and potential ecological risks in Iskenderun Bay were studied based on sediment samples collected there. The enrichment and contamination factors indicated a significant moderate accumulation of the metals. Although the calculated ecological risk values for As and $\mathrm{Ni}$ exceeded the maximum limits at several sites, they were generally below the permissible limits. The integrated $R I$ value for all metals indicated a moderate potential ecological risk at Sites 3 and 4 . Metal concentrations in Iskenderun Bay are not currently at levels that pose a risk to the ecosystem. Further, As and $\mathrm{Ni}$, which have the highest ecological risk values, are not correlated with other elements, suggesting that they reach the ecosystem through different pathways. Furthermore, it is extremely important to prevent an increase in $\mathrm{Cd}$ and $\mathrm{Hg}$ concentrations, which are currently at the maximum levels, so that the ecosystem of the bay is protected. Moreover, high environmental and ecological indices can be associated with the presence of industrial facilities, thermal power plants, and agricultural land in this region, and the fact that it is a wastewater discharge area. For the future of the bay, necessary measures should be taken to protect it from industrial pollution.

\section{Acknowledgements}

This research is supported by a Grant (Grant No. PPMUBO18-09) from The Scientific Research Projects Coordination Unit at Munzur University

\section{References}

Acevedo-Figueroa, D., Jiménez, B.D. \& Rodríguez-Sierra, C.J. (2006). Trace metals in sediments of two estuarine lagoons from Puerto Rico. Environmental Pollution 141: 336-342. DOI: 10.1016/j.envpol.2005.08.037.

Adamu, C.I., Nganje, T.N. \& Edet, A. (2015). Heavy metal contamination and health risk assessment associated with abandoned barite mines in Cross River State: southeastern
Nigeria. Environmental Nanotechnology, Monitoring and Management 3: 10-21. DOI: 10.1016/j.enmm.2014.11.001.

Alharbi, T. \& El-Sorogy, A. (2017). Assessment of metal contamination in coastal sediments of Al-Khobar area, Arabian Gulf, Saudi Arabia. Journal of African Earth Sciences 129: 458-468. DOI: 10.1016/j.jafrearsci.2017.02.007.

Anderson Abel, D.S.M, Kate, S., Werner, K., Marco, T. \& Christiane, Z. (2016). Metal fate and effects in estuaries: a review and conceptual model for better understanding of toxicity. Science of The Total Environment 541: 268-281. DOI: 10.1016/j.scitotenv.2015.09.045.

Bing, H., Wu, Y., Nahm, W-H. \& Liu, E. (2013). Accumulation of heavy metals in the lacustrine sediment of Longgan Lake, middle reaches of Yangtze River, China. Environmental Earth Sciences 69: 2679-2689. DOI: 10.1007/s12665-0122090-4.

Chakravarty, M. \& Patgiri, A. (2009). Metal Pollution Assessment in Sediments of the Dikrong River, N. E. India. Journal of Human Ecology 27: 63-67.

Chen, S., Chmura, G.L., Wang, Y., Yu, D., Ou, D. et al. (2019). Benthic microalgae offset the sediment carbon dioxide emission in subtropical mangrove in cold seasons. Limnology and Oceanography 64: 1297-1308. DOI: 10.1002/Ino.11116.

Cubadda, F., Conti, M.E. \& Campanella, L. (2001). Sizedependent concentrations of trace metals in four Mediterranean gastropods. Chemosphere 45: 561-569. DOI: 10.1016/S0045-6535 (01)00013-3.

Çevik, F., Göksu, M.Z.L., Derici, O.B. \& Findik, Ö. (2009). An assessment of metal pollution in surface sediments of Seyhan dam by using enrichment factor, geoaccumulation index and statistical analyses. Environmental Monitoring and Assessment 152: 309-317. DOI: 10.1007/s10661-0080317-3.

Datta, P.K., Ray, A.K., Sharma, V.K. \& Millero, F.J. (2004). Adsorption of Arsenate and Arsenic on Titanium Dioxide Suspensions. Journal Colloid Interface Science 278(2): 270 275. DOI: 10.1016/j.jcis.2004.06.015.

Dhanakumar, S., Solaraj, G. \& Mohanraj, R. (2015). Heavy metal partitioning in sediments and bioaccumulation in commercial fish species of three major reservoirs of river Cauvery delta region, India. Ecotoxicology and Environmental Safety 113: 145-151.

Dural, M. \& Göksu, M.Z.L. (2006). Variations of heavy metal levels of seston benthos and sediment seasonally in Çamlik Lagoon (Karataş, Adana). Ege Journal of Fisheries and Aquatic Sciences (EgeJFAS) 23(1/1): 65-69 (In Turkish).

Duysak, Ö. \& Ersoy, B. (2014). A biomonitoring study: heavy metals in Monodonta turbinata (Mollusca: Gastropoda) from Iskenderun Bay, North-Eastern Mediterranean. Pakistan Journal of Zoology 46(5): 1317-22.

Duysak, Ö., Ersoy, B. \& Dural, M. (2013). Metal concentrations in different tissues o cuttlefish (Sepia officinalis) in Iskenderun Bay, Northeastern Mediterranean. Turkish 
Journal of Fisheries and Aquatic Sciences 13: 205-210. DOI: 10.4194/1303-2712-v13_2_02.

EPA. (1995). Summary of Guidelines For Contaminated Freshwater Sediments-1995.

Fujita, M., Yamanoi, K. \& Izumiyama, H. (2014). A Combined Model of Sediment Production, Supply and Transport. Proceedings of the International Association of Hydrological Sciences 367: 357-365.

García, E.M., Cruz-Motta, J.J., Farina, O. \& Bastidas, C. (2008). Anthropogenic influences on heavy metals across marine habitats in the western coast of Venezuela. Continental Shelf Research 28(20): 2757-2766. DOI: 10.1016/j. csr.2008.09.020.

Guo, W., Liu, X., Liu, Z. \& Li, G. (2010). Pollution and potential ecological risk evaluation of heavy metals in the sediments around Dongjiang Harbor, Tianji. Procedia Environmental Sciences 2: 729-736.

Håkanson, L. (1980). An ecological risk index for aquatic pollution control: A sedimentological approach. Water Research 14: 975-1001.DOI: 10.1016/0043-1354(80)901438.

Hou, D., He, J., Lu, C., Ren, L., Fan, Q., et al. (2013). Distribution characteristics and potential ecological risk assessment of heavy metals $(\mathrm{Cu}, \mathrm{Pb}, \mathrm{Zn}, \mathrm{Cd})$ in water and sediments from Lake Dalinouer, China. Ecotoxicology and Environmental Safety 93: 135-144. DOI: 10. 1016/j.ecoenv.2013.03.012.

Huang, F., Xu, Y., Tan, Z., Wu, Z., Xu, H. et al. (2018). Assessment of pollutions and identification of sources of heavy metals in sediments from west coast of Shenzhen, China. Environmental Science and Pollution Research 25: 36473656. DOI: 10.1007/s11356-017-0362-y.

Kalay, M., Ay, Ö. \& Canli, M. (1999). Heavy metal concentrations in fish tissues from the Northeast Mediterranean Sea. The Bulletin of Environmental Contamination and Toxicology 63: 673-681. DOI: 10.1007/s001289901033.

Kargın, F., Coğun, H.Y., Yüzereroğlu, T.A., Fırat, Ö. \& Gök, G. (2006). Metal Concentrations in fish species from the northeast Mediterranean Sea. Environmental Monitoring and Assessment 121: 431-438.

Lollar, B. (2005). Environmental Geochemistry. First Edition. Amesterdam: Elsevier Science.

Long, E.R., Ingersoll, C.G. \& MacDonald, D.D. (2006). Calculation and uses of mean sediment quality guideline quotients: A critical review. Environmental Science and Technology 40: 1726-1736. DOI: 10.1021/es058012d.

Machado, W., Sanders, C.J., Santos, I.R., Sanders, L.M., SilvaFilho, E.V. et al. (2016). Mercury dilution by autochthonous organic matter in a fertilized mangrove wetland. Environmental Pollution 213: 30-35. DOI: 10.1016/j. envpol.2016.02.002.

Mohiuddin, K.M., Zakir, H.M., Otomo, K., Sharmin, S. \& Shikazono, N. (2010). Geochemical distribution of trace metal pollutants in water and sediments of downstream of an urban river. International Journal of Environmental
Science and Technology 7(1): 17-28. DOI: 10.1007/ BF03326113.

Olgunoğlu, M.P.P. \& Polat, S. (2007). Seasonal changes of heavy metals in two macroalgae species [Cystoseira corniculata (Phaeophyta), Laurencia papillosa (Rhodophyta)] in the Iskenderun Bay. Ege Journal of Fisheries and Aquatic Sciences (EgeJFAS) 24(1-2): 25-30 (In Turkish).

Özcan, T., Katağan, T. \& Peter, K.N.L. (2010). First record of Eurycarcinus integrifrons De Man 1879 (Decapoda, Pilumnidae) from the Mediterranean Sea. Crustaceana 83(4): 507-510.

Skordas, K., Kelepertzis, E. \& Kosmidis, D. (2015). Assessment of nutrients and heavy metals in the surface sediments of the artificially lake water reservoir Karla, Thessaly, Greece. Environmental Earth Sciences 73: 4483-4493. DOI: 10.1007/ s12665-014-3736-1.

Suresh, G., Ramasamy, V., Meenakshisundaram, V., Venkatachalapathy, R. \& Ponnusamy, V. (2011). Influence of mineralogical and heavy metal composition on natural radionuclide concentrations in the river sediments. Applied Radiation and Isotopes 69(10): 1466-1474. DOI: 10.1016/j.apradiso.2011.05.020.

Sutherland, R. (2000). Bed sediment-associated trace metals in an urban stream, Oahu, Hawaii. Environmental Geology 39(6): 611-627.

Türkmen, A. \& Aras, S. (2011). Investigation of heavy metal accumulation in sea water and sediment in İskenderun Bay. Journal of Black Sea Science 1-23.

Vrhovnik, P., Šmuc, N.R., Dolenec, T., Serafimovski, T. \& Dolenec, M. (2013). An evaluation of trace metal distribution and environmental risk in sediments from the Lake Kalimanci (FYR Macedonia). Environmental Earth Sciences 70(2): 761775. DOI: 10.1007/s12665-012-2166-1.

Wei, B.G. \& Yang, L.S. (2010). A review of heavy metal contaminations in urban soils, urban road dusts and agricultural soils from China. Microchemical Journal 94(2): 99-107. DOI: 10.1016/j.microc.2009.09.014.

Yalcin, M.G., Coskun, B., Nyamsari, D.G. \& Yalcin, F. (2019). Geomedical, ecological risk, and statistical assessment of hazardous elements in shore sediments of the Iskenderun Gulf, Eastern Mediterranean, Turkey. Environmental Earth Sciences 78: 438. DOI: 10.1007/ s12665-019-8435-5.

Yang, Q., Lei, A.P., Li, F.L., Liu, L.N., Zan, Q.J. et al. (2014). Structure and function of soil microbial community in artificially planted Sonneratia apetala and S. caseolaris forests at different stand ages in Shenzhen Bay, China. Marine Pollution Bulletin 85: 754-763. 